\title{
A Stepwise Inquiry Approach to Improving Communication Skills and Scientific Attitudes on a Biochemistry Course
}

\section{Wildan Wildan}

Dr., Universitas Mataram, Indonesia, wildanfkip@ unram.ac.id

\author{
Aliefman Hakim \\ Dr., Universitas Mataram, Indonesia, aliefman@unram.ac.id
}

\section{Jeckson Siahaan}

Mr., Universitas Mataram, Indonesia, siahaanjackson251@yahoo.com

\section{Yunita Arian Sani Anwar}

Dr., corresponding author, Universitas Mataram, Indonesia, yunita@ unram.ac.id

The present study aims to examine the implementation of a stepwise inquiry approach to improving communication skills and scientific attitudes. Stepwise inquiry comprises structured inquiry, guided inquiry, and open inquiry. The variables measured were communication skills and scientific attitudes. The construct used to measure communication skills involved written, verbal, and social communication skills, along with scientific attitude indicators including curiosity, openness of mind, objectivity, honesty in reporting results, responsibility, and mutual respect. The design of the study employed a posttest-only control group design with an experimental class of 20 students and a control class of 21 students. The effect of stepwise inquiry implementation was analyzed using MANOVA. The results reveal that the classes implementing stepwise inquiry had higher scores for communication skills and scientific attitudes than those undertaking expository approaches. The implementation of stepwise inquiry significantly affects the scores of scientific communication and attitude skills based on MANOVA analysis. The involvement of students independently in the investigation process increases their ability to construct knowledge and build arguments, in addition to increasing their motivation for learning. This established motivation enables the formation of positive attitudes, such as scientific attitudes, in the students.

Keywords: biochemistry, communication skills, inquiry, laboratory work, scientific attitudes

Citation: Wildan, W., Hakim, A., Siahaan, J., \& Anwar, Y. A. S. (2019). A Stepwise Inquiry Approach to Improving Communication Skills and Scientific Attitudes on a Biochemistry Course. International Journal of Instruction, 12(4), 407-422. https://doi.org/10.29333/iji.2019.12427a 


\section{INTRODUCTION}

Current learning not only requires students to be able to remember concepts but must also be capable of training students in the skills required for their future needs. Verbal and written communication are two skills that students need to master as an indicator of their readiness to face life (Saavedra \& Opfer, 2012; Wagner, 2008, p. 5). Communication skills are important not only for training critical thinking skills but also for building long-term concepts (Reynolds et al., 2012).

Laboratory-based learning is one method suited to training in many skills, especially direct practices and communication skills (Anwar et al., 2018; Bramer \& Bastin, 2013; Burnham, 2013; Carr, 2013). There are four types of laboratory-based learning, namely expository, inquiry, discovery, and problem-based. This type of learning is divided into three descriptors, namely outcome, approach, and procedure (Johnstone, 2006). The descriptors for each type of laboratory-based learning are shown in Table 1.

Table 1

Descriptors for Laboratory Instruction Styles

\begin{tabular}{lllll}
\hline \multirow{2}{*}{ No. } & \multicolumn{2}{|c}{ Type } & \multicolumn{3}{c}{ Descriptor } \\
\cline { 3 - 5 } & Outcome & Approach & Procedure \\
\hline 1. & Expository & Predetermined & Deductive & Provided \\
2. & Inquiry & Undetermined & Inductive & Student generated \\
3. & Discovery & Predetermined & Inductive & Provided \\
4. & Problem-based & Predetermined & Deductive & Student generated \\
\hline
\end{tabular}

The chemistry curriculum in higher education stipulates laboratory work as a place to develop students' ideas and thought processes as a whole. Laboratory work is carried out not solely to improve psychomotor skills but also to enhance problem-solving ability and help to develop student attitudes (Mbajiorgu \& Reid, 2006). This requires the development of learning-based laboratory work capable of providing greater opportunities for students to study investigations in the laboratory, with more support (Holbrook \& Rannikmae, 2007).

The facts in the field indicate a range of problems associated with the implementation of laboratory work in higher education. Laboratory work remains dominated by expository methods, which means it has not been effective in the training of critical thinking skills (Anwar et al., 2017a). In addition, laboratory work has not been developed with the aim of training student communication skills (Anwar et al., 2017b).

Laboratory-based learning in higher education would thus be more effective if the tendency for it to be dominated by expository methods was removed (Monteyne \& Cracolice, 2004; Reid \& Shah, 2007; Sigler \& Saam, 2007). More students would be provided with the opportunity to prepare an investigation process enabling them to understand the procedures required for the examination (Ginger et al., 2012; Limoto \& Frederick, 2011; Tsaparlis \& Gorezi, 2007). One approach that can be applied to the training of student skills is the inquiry approach (Cacciotore \& Sevian, 2009; Fakayode, 2014). 
Inquiry is related to constructivism theories that describe the constructs of knowledge that are built and tested so that they are feasible to apply (Johnstone, 2006). The ability of students to construct knowledge can lead to new understandings that help them build relationships between concepts. In addition, inquiry activities can develop students' motivation to learn and improve their scientific attitudes (Ketpichainarong et al., 2010). The inquiry approach is highly suited to courses that involve laboratory work as part of the learning process.

Inquiry is divided into four levels, namely verification (level 0), structured inquiry (level 1), guided inquiry (level 2), and open inquiry (level 3) (Fay et al., 2007). The use of open and guided inquiry has been reported to be able to improve student understanding in chemistry learning (Allen et al., 1986; Bartholow, 2007; Conway, 2014; Johnson \& Graham, 2015; Rens \& Schee, 2009; Sedwick et al., 2018; Winkelmann et al., 2015; Xu $\&$ Talanquer, 2013). However, the direct application of guided and open inquiry may make students uncomfortable because they are accustomed to conducting investigations with procedures as directed by lecturers (Chatterjee et al., 2009; Cheung, 2011). Up to now, the use of inquiry in stages has not been widely reported, especially in the context of biochemistry learning in higher education.

\section{Communication Skills}

Communication skills are defined as a person's ability to provide information that is easily understood by others (Iksan et al., 2012; Khan et al., 2017). They can also be defined as the ability to deliver and give information, and as speaking and writing ability (McCroskey \& McCroskey, 1988). There are four elements that support communication skills, namely the speaker, listener, communication channel, and feedback.

Communication skills are divided into three types, namely writing, verbal, and social skills (Iksan et al., 2012). A person's writing skills demonstrate their ability to express ideas, opinions, and arguments in writing in ways that are easily understood by the reader. Verbal skills show a person's ability to express opinions, ideas, and arguments directly with polite words in a way that is easily understood by listeners. A person's social skills indicate their ability to interact with others in an effort to convey ideas, opinions, and arguments.

It is important that chemistry students are trained in writing skills as, through writing, students can practice critical thinking skills, develop effective verbal abilities, and practice learning skills over time (Quitadamo \& Kurtz, 2007). In addition, writing skill can provide reinforcement in the cognitive domain (Dresner et al., 2014).

\section{Scientific Attitude}

Scientific attitude is a type of attitude that is both held and required in order to use scientific processes, and it features the knowledge acquired by a scientist through the processes carried out (Pitafi \& Farooq, 2012). Scientific attitudes describe openness of mind, curiosity, and an optimistic approach to failure as values that are closely related to scientific training. Attitudes are very important for all citizens (Abdullahi, 1982), and a scientific attitude is a combination of many qualities and virtues, which are reflected in 
behavior and actions. People who have a scientific attitude will be open-minded, experiment-oriented, and systematic in their approach. They tend to be intellectuals who have a love of knowledge, are honest, and who have a scientific spirit and hope that the solution to a problem can be derived through the use of verified knowledge (Jancirani et al., 2012).

Scientific attitude is included in the character education that must be possessed by students, and the implementation of learning is expected to be able to train the scientific attitude of students. A number of different elements make up a scientific attitude, including honesty, responsibility, curiosity, loyalty, critical, independent, openness, respecting the work of others, and thinking ahead (Balitbang, 2012). Kaur (2013) explained that scientific attitudes can be characterized by components such as openmindedness; curiosity; verification based on proven facts; a readiness to test and verify conclusions, cause and effect relationships, and reconsider decisions; freedom from superstition and false beliefs; honesty in recording, collecting, and reporting important scientific data in observation; accepting final conclusions, and trusting more in books written by experts in their respective fields. The scientific attitude includes the following habits of thought, namely the habit of accuracy in all operations, including accuracy in calculations, observations, and reports; intellectual honesty habits; open-minded habits; the habit of seeking out the right cause, and the influence of relationships and habits.

\section{METHOD}

\section{Research Design}

The current study used a posttest-only control group design consisting of two groups, namely an experimental group and a control group (Mertens, 2015). The experimental group received stepwise inquiry treatment and the control group received expository treatment that had been applied. The sample comprised 41 University of Mataram students undertaking a Biochemistry course; 21 students in the control group, and 20 students in the experimental group.

\section{Structure of the Stepwise Inquiry Approach}

This study was designed for chemistry students undertaking a Biochemistry course. The special lectures for the present study were conducted over a period of 8 weeks. Every week there were two face-to-face meetings in the class with a duration of 150 minutes, plus two to three hours of laboratory work. The content used in this study includes amino acids, proteins, and enzymes. The structure of the inquiry approach used in the study is shown in Table 2 . 
Table 2

The Structure of the Stepwise Inquiry Approach

\begin{tabular}{|c|c|}
\hline Level of Inquiry & Scenario \\
\hline $\begin{array}{l}\text { Structured } \\
\text { inquiry (Level } \\
\text { 1) }\end{array}$ & $\begin{array}{l}\text { 1. The lecturer explains the competencies to be achieved, learning activities, and } \\
\text { evaluation techniques. } \\
\text { 2. The lecturer explains the material structure, properties, and methods of } \\
\text { qualitative analysis of amino acids. } \\
\text { 3. The lecturer gives instructions to discuss the preparation of laboratory work to be } \\
\text { carried out on the qualitative analysis of amino acids. } \\
\text { 4. The lecturer explains how to qualitatively analyze amino acids. } \\
\text { 5. Students conduct investigations based on the procedures provided by the } \\
\text { lecturer. } \\
\text { 6. The students record the results of the investigation and prepare an investigation } \\
\text { report. } \\
\text { 7. The lecturer provides feedback on the investigations that have been conducted } \\
\text { and provides evaluations. }\end{array}$ \\
\hline $\begin{array}{l}\text { Guided inquiry } \\
\text { (Level 2) }\end{array}$ & $\begin{array}{l}\text { 1. The lecturer explains the competencies to be achieved, learning activities, and } \\
\text { evaluation techniques. } \\
\text { 2. The lecturer explains the material structure, properties, and methods of } \\
\text { qualitative and quantitative analysis of protein. } \\
\text { 3. The lecturer gives instructions to discuss the preparation of laboratory work to be } \\
\text { carried out on the qualitative and quantitative analysis of protein. } \\
\text { 4. Students develop procedures for the qualitative and quantitative analysis of } \\
\text { protein through literature. } \\
\text { 5. Students carry out an investigation based on the procedures they have compiled. } \\
\text { 6. The students record the results of their investigation and prepare an investigation } \\
\text { report. } \\
\text { 7. Students give presentations and discuss the results of the investigation. } \\
\text { 8. The lecturer provides feedback on the investigations conducted and provides } \\
\text { evaluations. }\end{array}$ \\
\hline $\begin{array}{l}\text { Open inquiry } \\
\text { (Level 3) }\end{array}$ & $\begin{array}{l}\text { 1. The lecturer explains the competencies to be achieved, learning activities, and } \\
\text { evaluation techniques. } \\
\text { 2. The lecturer explains the classification of enzymes, work mechanism, and factors } \\
\text { that affect enzymes. } \\
\text { 3. The lecturer gives instruction to discuss the preparation of laboratory work to be } \\
\text { carried out with the theme of protease. } \\
\text { 4. Students determine the problem to be investigated with the instructed theme. } \\
\text { 5. Students develop an investigation procedure in accordance with the problems } \\
\text { that have been prepared. } \\
\text { 6. Students carry out investigations in accordance with the procedures they have } \\
\text { compiled. } \\
\text { 7. Students record the results of their investigation and prepare an investigation } \\
\text { report. } \\
\text { 8. Students present and discuss the results of their investigation. } \\
\text { 9. The lecturer provides feedback on the investigations that have been conducted } \\
\text { and provides evaluations. }\end{array}$ \\
\hline
\end{tabular}

\section{Research Instrument}

This current study used two types of instruments suitable for the variables being measured, namely instruments to measure communication skills and scientific attitudes. The communication skills measured in the present study include written, verbal, and social communication skills. Written communication skills were measured based on the 
students' ability to compile investigative reports. The components of the investigative reports measured were the abstract, information sources, organization, relevance, content, and presentation (Hoyo, 2003). Verbal and social communication skills were measured based on the students' ability to report the results of their investigations and interact with their groups. The components of verbal and social communication skills included the students' communication skills at presentation, their ability to work together in teams, and the ability to locate information. Each component of communication skills had assessment criteria in the form of rubrics, with scores ranging from 1 to 4 .

The scientific attitude used in this study consisted of 6 categories, namely curiosity, openness of mind, objectivity, honesty in reporting results, responsibility, and mutual respect. Each category of attitude was developed into two indicators (Table 3), with each indicator developed into several positive and negative statements. Each statement was provided with five choices of answers, namely strongly agree, agree, hesitate, disagree, or strongly disagree. The communication skills rubric and scientific attitude questionnaire were tested for validity and reliability using the expert judgment of three experts. The expert judgment analysis showed that the instrument was valid and reliable.

Table 3

Categories and Indicators of Scientific Attitudes

\begin{tabular}{lll}
\hline No. & Categories & Indicators \\
\hline 1. & Curiosity & $\begin{array}{l}\text { a. Has a scientific interest in biochemistry } \\
\text { b. Interest in information related to biochemistry }\end{array}$ \\
\hline 2. & Openness of mind & $\begin{array}{l}\text { a. Interest in attaining more information } \\
\text { b. Accepts the opinions of others }\end{array}$ \\
\hline 3. & Objectivity & $\begin{array}{l}\text { a. Is objective } \\
\text { b. Is able to distinguish facts and opinions }\end{array}$ \\
\hline 4. & Honesty & $\begin{array}{l}\text { a. Behaves in a way or says things consistent with the facts } \\
\text { b. Does not overstate and understate }\end{array}$ \\
\hline 5. & Responsibility & $\begin{array}{l}\text { a. Completes tasks on time } \\
\text { b. Carries out the task based on the lecturer's guidance }\end{array}$ \\
\hline 6. & Mutual respect & a. Respects team members \\
& & b. Respects the biochemistry lecturer
\end{tabular}

\section{Data Analysis Technique}

The mean score for each measured variable for the control group and experimental group was calculated. The effect of stepwise inquiry implementation was analyzed using MANOVA with SPSS 21 (IBM SPSS Statistic 21). Supporting data were obtained by eliciting the opinions of the students regarding the implementation of the stepwise inquiry approach. The opinions and suggestions from students were then analyzed and described in the form of free response data.

\section{FINDINGS}

The results of the study show that the mean score for communication skills of the class implementing stepwise inquiry $(\mathrm{M}=81.30 ; \mathrm{SD}=6.45)$ was higher than that of the class 
applying expository learning $(\mathrm{M}=65.83 ; \mathrm{SD}=7.05)$. The scores of the three constructs indicate that the implementation of stepwise inquiry increases the ability of students to communicate in written, verbal, and social form. In the experimental class, the average scores for written, verbal, and social communication skills were 69.35, 58.33, and 69.81, respectively, while the scores obtained by the control class were 78.75, 76.69, and 85.45 respectively. The mean scores for communication skills in the two classes are shown in Figure 1.

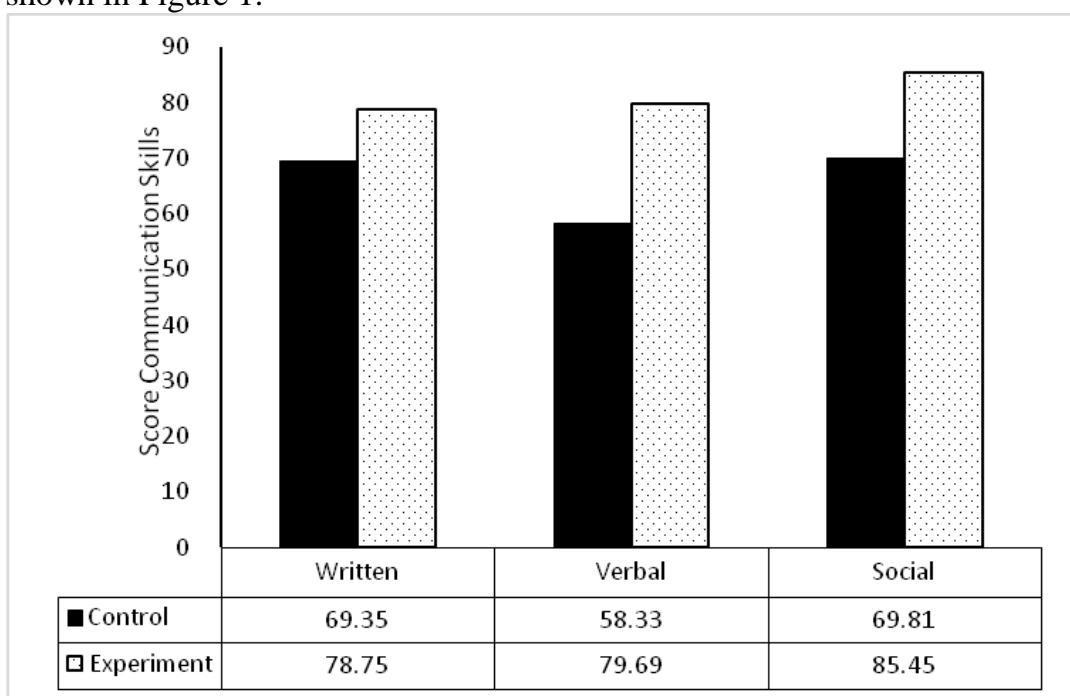

Figure 1

Scores of Communication Skills of the Control Group and Experimental Group

The ability of the students to produce inquiry in the class applying stepwise inquiry is thus shown to be better than that of the students in the class implementing an expository approach. In addition, the students seemed to have more control over the topic of investigation when presenting the results of their investigations. The contribution of group members during the presentations was more evenly distributed and all group members were able to answer questions from the participants well. In the class with an expository approach, the students read more presentation slides, which meant they did not master the topic of investigation. The contribution of the team members did not appear to be well distributed, and one only group member answered questions from the participants.

The scientific attitude score in the class with stepwise inquiry implementation $(\mathrm{M}=$ 87.67; $\mathrm{SD}=2.67$ ) was higher than that of the class that applied the expository approach. The scores of the six scientific attitude categories showed the highest value in the class implementing stepwise inquiry compared with the class applying the expository approach (Figure 2). In the control class, the responsibility category shows the highest value $(\mathrm{M}=77.14)$, while curiosity has the lowest score $(\mathrm{M}=68.57)$. Unlike the experimental class, the highest score is shown in the curiosity category $(\mathrm{M}=89.33)$. 


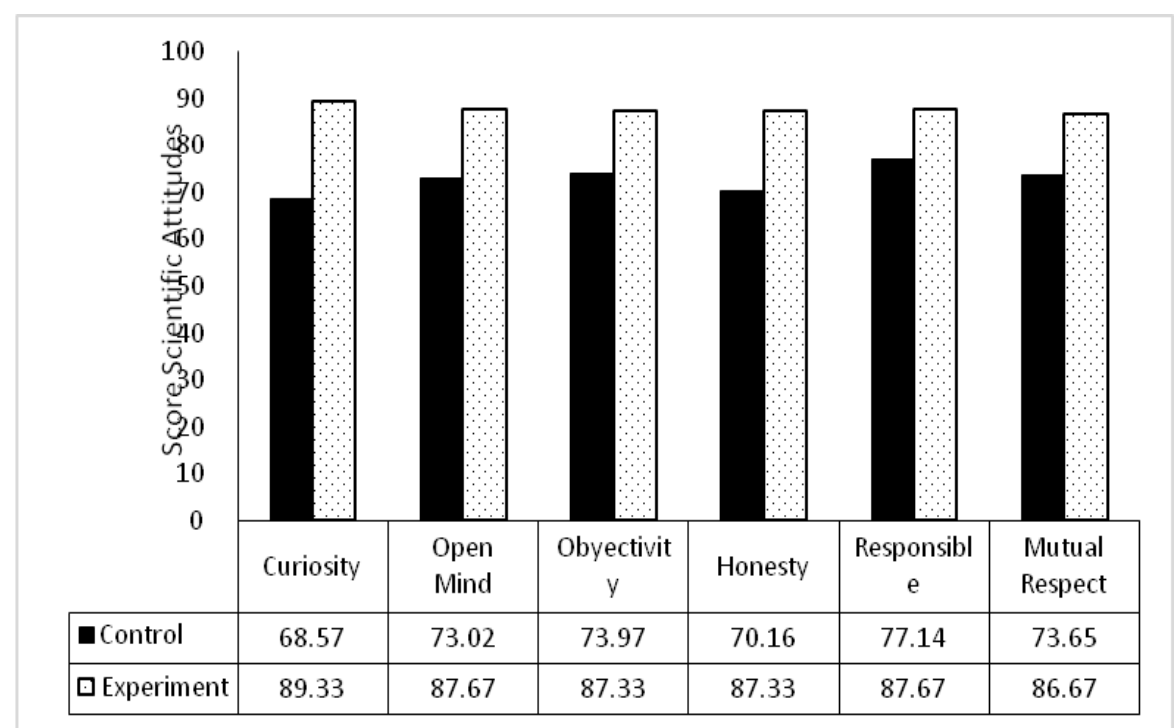

Figure 2

Scores of Scientific Attitudes in the Control and Experimental Classes

The MANOVA test is used to analyze the relationship between the implementation of stepwise inquiry and communication skills and scientific attitudes. The Box's M test value has a significance of 0.643 and the Levene test has $F$ test scores for communication skills and scientific attitudes of 0.004 and 0.232 respectively ( $p>0.05)$, thus indicating that the variance matrix of the dependent variables is the same. This satisfies the MANOVA assumption, meaning the analysis can be continued. The implementation of stepwise inquiry has a significant influence on the communication skills and scientific attitudes of students ( $\mathrm{p}<0.05)$. The values of the adjusted $\mathrm{R}$ squared for communication skills and scientific attitudes are $56.8 \%$ and $90 \%$ respectively.

\section{DISCUSSION}

The implementation of stepwise inquiry is aimed at reducing the application of expository methods in biochemistry learning. According to Reid and Shah (2007), laboratory-based learning should not be dominated by the cookbook laboratory; instead, it should provide more opportunities for students to be able to prepare their investigations. While expository can be used as a first step to familiarize students with conducting investigations (Ault, 2002), if high-level inquiry is then applied directly, it can make students uncomfortable as they have become accustomed to conducting investigations according to procedures laid down by their lecturers (Chatterjee et al., 2009; Cheung, 2011).

The stepwise inquiry applied in this study ranges from the lowest to the highest level. The application of the method in stages offers the ability to integrate the topic and procedure of investigation so that the students can understand each stage of the 
investigation (Kakisako et al., 2016). In addition, following the staged method means that students can be trained gradually in the skills needed to conduct investigations (Bennett \& O’Neal, 1998; Hunter et al., 2003).

The lowest level of inquiry used is structured inquiry, which involves more lecturers in the learning process. The lecturer sets out the procedure of investigation, and the students only follow the procedures given. Structured inquiry experiment classes can be considered as "pre-learning" to help students plan their next investigation with a higher level of inquiry (Burnham, 2013; Cacciatore \& Sevian, 2009; Johnstone, 1997; Jolley et al., 2016; Rollnick et al., 2001).

The use of the second level of inquiry provides students with something different. If the student has previously been provided with an inquiry procedure by the lecturer, then the second stage involves the student beginning to be trained in forming his own investigation procedures. The preparation of an independent inquiry procedure benefits the learning process. The benefits of organizing independent inquiry procedures are that investigative procedures are easy to understand, the theoretical basis can be strengthened, it helps to build arguments, and student thinking skills are improved (Burnham, 2013; Dresner et al., 2014; Fakayode, 2014; Hakim et al., 2016; Hakim \& Jufri, 2017; Hakim et al., 2018; Hakim \& Jufri, 2018; Miller \& Lang, 2016; Walker \& Sampson, 2013). If students are able to carry out a well-planned inquiry process, it can increase their motivation for subsequent investigations (Limoto \& Frederick, 2011; Miller \& Lang, 2016; Tsaparlis \& Gorezi, 2007).

Students can find implementing investigation procedures that they have planned to be difficult and challenging (McDonnell et al., 2007). Through the implementation of their investigation plan, students can be trained in using the instruments in the laboratory, carrying out investigative procedures, correctly recording investigation data, analyzing inquiry data, presenting data systematically, and interpreting investigative data (Hensiek et al., 2016; Reid \& Shah, 2007). The skills described above make it easier for students to compile investigative reports as well as report the results of investigations through presentations in class (Anwar et al., 2018). If the investigation process runs according to the plan that has been prepared, the students have greater confidence in the next investigation (Gaddis \& Schoffstall, 2007; Gasper \& Gardner, 2013; Pickering, 1987).

Open inquiry is applied after guided inquiry by giving students the opportunity to determine problems, develop investigation procedures, and interpret data. In the group applying the stepwise inquiry, the source of the protease enzyme being studied used waste such as that from pineapples and papayas. Meanwhile, in the class with an expository approach, the protease enzyme tested had already been determined by the lecturer, and the students only followed the procedures contained in the laboratory work instructions. Prior to starting the investigation, the lecturer was consulted on the students' draft inquiry with a view to reducing possible errors (Deters, 2005; Lechtanski, 2001).

The implementation of open inquiry as the highest level of inquiry has similarities with the assigning of projects to students during the learning process. The students' 
independence in planning and implementing an investigation plan leads to them acting as initiators in terms of supporting the development of their own thinking and communication skills (King et al., 2018; Rootman-le Grange \& Retief, 2018; Velasco et al., 2016). When conducting an investigation, students are more familiar with the procedures that they followed, thus making it easier for them to explain to the participants in the discussion. The inquiry approach is not only beneficial for the students, but also useful for the lecturers in that it allows them to design better learning, modify more interesting inquiry procedures, and establish more intense communication with students (Burnham, 2013; Lechtanski, 2001; Rootman-le Grange \& Retief, 2018).

The ability to compile laboratory work reports is important in the development of student communication skills (Bramer \& Bastin, 2013). Through writing, students can better understand content through the ability to construct new knowledge and ideas (Sampson et al., 2013). The task of compiling an investigation report can encourage students to think in real terms and develop arguments to facilitate their presentation in class (Duzor, 2016; Visser et al., 2018).

The comments raised by the students indicated a positive response to the application of stepwise inquiry. The students felt happy and motivated when conducting investigations. The presentation of the results of the investigation was part of the learning that students greatly favored because they were more aware of the purpose of each stage of the investigation procedure that they had carried out. According to the MotivationOpportunity-Determinant (MODE) model, learning has the ability to determine the formation of attitudes, including scientific attitudes. Scientific attitudes and other positive attitudes are very meaningful in developing thinking skills and other skills (Ajzen \& Fishbein, 2005).

In traditional laboratory work, the students merely followed the procedures of laboratory work as described in the laboratory work manual, and they typically did not understand each stage well. While the students still asked questions - such as why does enzyme isolation use buffer when making crude enzyme; what are the functions of TCA in protease measurement activity? - these were different from the experimental class where the open inquiry approach used to study the topic of enzyme demanded students' independence in following the inquiry procedures. This leads students to learn and understand each stage required in the inquiry process.

\section{CONCLUSION}

The results of this study indicate that the implementation of a stepwise inquiry approach had a positive effect on the students' communication skills and scientific attitudes. Scores in writing, verbal, and social skills, and the six scientific attitude categories were higher in the experimental class than the control class. In addition, the students demonstrated a positive response to the application of a stepwise inquiry approach.

The use of the inquiry approach gradually gives students the opportunity to design the investigation process. This gradual implementation, starting with an inquiry structure and building to open inquiry, functions to train students gradually and reduce the discomfort that arises from them being accustomed to using traditional laboratories. 
Based on the results of this study, the recommendation is that a stepwise inquiry approach can be applied to laboratory-based science learning so as to reduce the dominance of expository methods in the implementation of laboratory work in higher education.

\section{LIMITATIONS OF THE STUDY}

The current study has several limitations. First, this study uses a limited number of respondents. Second, the study did not apply the four levels of the inquiry in the group, meaning the effect of the three variables at each level of inquiry has not been examined in this study.

\section{ACKNOWLEDGMENTS}

We would like to express our gratitude to the innovation grant as a funder of the present study. We are also grateful to the students, observers, and learning assistants who played an active role, either directly or indirectly, during the research process.

\section{REFERENCES}

Abdullahi, A. (1982). Science teaching in Nigeria. Ilorin: Atoto Press Limited.

Ajzen, I., \& Fishbein, M. (2005). The influence of attitudes on behavior. In D. Albarracín, B. T. Johnson, \& M. P. Zanna (Ed.), The handbook of attitudes (pp. 173221). Mahwah, NJ: Lawrence Erlbaum and Associates.

Allen, J. B., Barker, L. N., \& Ramsden, J. H. (1986). Guided inquiry laboratory. Journal of Chemical Education, 63(6), 533-534. doi: 10.1021@ed063p533.

Anwar, Y. A. S., Senam, S., \& Laksono, E. W. (2017a). Effective laboratory work in biochemistry subject: Students' and lecturers' perspective in Indonesia. International Journal of Higher Education, 6(2), 100-109. doi: 10.5430/ijhe.v6n2p100.

Anwar, Y. A. S., Senam, S., \& Laksono, E. W. (2017b). Identification of the students' critical thinking skills through biochemistry laboratory work report. Paper presented at the $4^{\text {th }}$ International Conference on Research, Implementation, and Education of Mathematics and Science, Universitas Negeri Yogyakarta, 15-16 May 2017. doi: 10.1063/l.4995112.

Anwar, Y. A. S., Senam, S., \& Laksono, E. W. (2018). The use of orientation/decision/do/discuss/reflect (OD3R) method to increase critical thinking skill and practical skill in biochemistry learning. Biochemistry and Molecular Biology Education, 46(2), 107-113. doi: 10.1002/bmb.21096.

Ault, A. (2002). What's wrong with cookbooks? Journal of Chemical Education, 79(10), 1177. doi: 10.1021/ed081p1559.

Balitbang (2011). Panduan pelaksanaan pendidikan karakter. Jakarta: Puskorbuk Kemendikbud. 
Bartholow, M. (2007). A class inquiry into Newton's cooling curve. Journal of Chemical Education, 84(10), 1684. doi: 10.1021/ed084p1684.

Bennett, S. W., \& O’Neal, K. (1998). Skills development and practical work in chemistry. University Chemistry Education, 2, 58-62.

Bramer, S. E. V., \& Bastin, L. D. (2013). Using a progressive paper to develop students' writing skill. Journal of Chemical Education, 90(6), 745-750. doi: 10.1021/ed300312q.

Burnham, J. A. J. (2013). Opportunistic use of students for solving laboratory problems: Twelve heads are better than one. NDIR, 9(1), 42-48. doi: 10.11120/ndir.2013.00003.

Cacciatore, K. L., \& Sevian, H. (2009). Incrementally approaching an inquiry lab curriculum: Can changing a single laboratory experiment improve student performance in general chemistry? Journal of Chemical Education, 86(4), 498-505. doi: 10.1021/ed086p498.

Carr, J. M. (2013). Using a collaborative critiquing technique to develop chemistry students' technical writing skills. Journal of Chemical Education, 90(6), 751-754. doi: 10.1021/ed2007982.

Chatterjee, S., Williamson, V. M., McCann, K., \& Peck, M. L. (2009). Surveying students' attitudes and perceptions toward guided-inquiry and open-inquiry laboratories. Journal of Chemical Education, 86(12), 1427. doi: 10.1021/ed086p1427.

Cheung, D. (2011). Teacher beliefs about implementing guided-inquiry laboratory experiments for secondary school chemistry. Journal of Chemistry Education, 88, 14621468. doi: 10.1021/ed.1008409.

Conway, J. C. (2014). Effects of guided inquiry versus lecture instruction on final grade distribution in a one-semester organic and biochemistry course. Journal of Chemical Education, 91(4), 480-483. doi: 10.1021/ed300137z.

Deters, K. M. (2005). Student opinions regarding inquiry-based labs. Journal of Chemical Education, 82(8), 1178-1180. doi: 10.1021/ed082p1178.

Dresner, M., De Rivera, C., Fuccillo, K. K., \& Chang, H. (2014). Improving higherorder thinking and knowledge retention in environmental science teaching. Bioscience, 64(1), 40-48. doi: 10.1093/biosci/bit005.

Duzor, A. G. V. (2016). Using self-explanations in the laboratory to connect theory and practice: The decision/explanation/observation/inference writing method. Journal of Chemical Education, 93(10), 1725-1730. doi: 10.1021/acs.jchemed.6b00093.

Fakayode, S. O. (2014). Guided-inquiry laboratory experiments in the analytical chemistry laboratory curriculum. Analytical and Bioanalytical Chemistry, 406, 1267 1271. doi: 10.1007/s00216-013-7515-8.

Fay, M. E., Grove, N. P., Towns, M. H., \& Lowery, S. (2007). A rubric to characterize inquiry in the undergraduate chemistry laboratory. Chemistry Education Research and Practice, 8(2), 212-219. 
Gaddis, B. A., \& Schoffstall, A. M. (2007). Incorporating guided-inquiry learning into the organic chemistry laboratory. Journal of Chemical Education, 84(5), 848-851. doi: $10.1021 @$ ed084p848.

Gasper, B. J., \& Gardner, S. M. (2013). Engaging students in authentic microbiology research in an introductory biology laboratory course is correlated with gains in student understanding of the nature of authentic research and critical thinking. Journal of Microbiology and Biology Education, 14(1), 25-34. doi: 10.1128/jmbe.v14i1.460.

Ginger, J., McGrath, R., Barrett, B., \& McCreary, V. (2012). Mini labs: Building capacity for innovation through a local community fab lab network. Interaction, 18(5), 86-87. doi: 10.1145/2008176.2008196.

Hakim, A., Liliasari, L., Kadarohman, A., \& Syah, Y. M. (2016). Improvement of student critical thinking skills with the natural product mini project laboratory learning. Indonesian Journal of Chemistry, 16(3), 315-321.

Hakim, A., \& Jufri, A. W. (2017). Applications of isolation and structure elucidation of secondary metabolites in natural product chemistry laboratory. In J. C. Taylor (Ed.), Advances in chemistry research, Volume 35. New York, NY: NOVA Science Publishers Inc. (ISBN: 978-1-53610-734-0).

Hakim, A., Andayani, Y., \& Rahayuan, B. D. (2018). Isolation of Ethyl P-Methoxy Cinnamate from Kaemferia galanga. Journal of Physics: Conf. Series, 1095:012039. doi: 10.1088/1742-6596/1095/1/012039.

Hakim, A., \& Jufri, A. W. (2018). Natural products laboratory project: Isolation and structure elucidation of piperin from piper nigrum and andrographolide from Andrographis paniculata. Journal of Turkish Science Education, 15(4), 15-28.

Hensiek, S., DeKorver, B. K., Harwood, C. J., Fish, J., O’Shea, K., \& Towns, M. (2016). Improving and assessing student hands-on laboratory skills through digital badging. Journal of Chemical Education, 93(11), 1847-1854. doi: 10.1021/acs.jchemed.6b00234.

Holbrook, J., \& Rannikmae, M. (2007). The nature of science education for enhancing scientific literacy. International Journal Science and Education, 29, 1347-1362. doi: 10.1080/09500690601007549.

Hoyo, M. T. (2003). Designing a written assignment to promote the use of critical thinking skills in an introductory chemistry course. Journal of Chemical Education, 80(8), 899-903. doi: 10.1039/B2RP90038F.

Hunter, C., McCosh, R., \& Wilkins, H. (2003). Integrating learning and assessment in laboratory work. Chemistry Education: Research and Practice, 4(1), 67-75. doi: 10.1039/B2RP90038F.

Iksan, Z. H., Zakaria, E., Meerah, T. S. M., Osman, T., Lian, D. K. C., Mahmud, S. N. D., \& Krish, P. (2012). Communication skills among university students. Procedia Social and Behavioral Sciences, 59, 71-76. 
Jancirani, R., Dhevakrishnan, R., \& Devi, S. (2012). A study on scientific attitude of adolescence students in Namakkal District. International Educational E-Journal, 1(4), 2-8. Retrieved from www.oiirj.org/ejournal/july-aug-sept2012/01.pdf.

Johnson, B. J., \& Graham, K. J. (2015). A guided inquiry activity for teaching ligand field theory. Journal of Chemical Education, 92(8), 1369-1372. doi: 10.1021/acs.jchemed.5b00019.

Johnstone, A. H. (1997). Chemistry teaching-science or alchemy? Journal of Chemical Education, 74(3), 262-268. doi: 10.1021/ed074p262.

Johnstone, A. H. (2006). Chemical education research in Glasgow in perspective. Chemistry Education Research and Practice, 7(2), 49-63. doi: 10.1039/B5RP90021B.

Jolley, D. F., Wilson, S. R., Kelso, C., O’Brien, G., \& Mason, C. E. (2016). Analytical thinking, analytical action: Using prelab video demonstrations and e-quizzes to improve undergraduate preparedness for analytical chemistry practical classes. Journal of Chemical Education, 93(11), 1855-1862. doi: 10.1021/acs.jchemed.6b00266.

Kakisako, M., Nishikawa, K., Nakano, M., Harada, K. S., Tatsuoka, T., \& Koga, N. (2016). Stepwise inquiry into hard water in a high school chemistry laboratory. Journal of Chemical Education, 93(11), 1923-1928. doi: 10.1021/acs.jchemed.6b00217.

Kaur, G. (2013). Scientific attitude in relation to critical thinking among teachers. Educationia Confab, 2(8), 24-29.

Ketpichainarong, W., Panijpan, B., \& Ruenwangsa, P. (2010). Enhanced learning of biotechnology students by an inquiry-based cellulase laboratory. International Journal Environmental \& Science Education, 5(2), 169-187. Retrieved from http://www.ijese.net/arama?all=\&author=Ketpichainarong

Khan, A., Khan, S., Zia-Ul-Islam, S., \& Khan, M. (2017). Communication skills of a teacher and its role in the development of the students' academic success. Journal of Education and Practice, 8(1), 18-21.

King, J. H. T., Wang, H., \& Yezierski, E. J. (2018). Asymmetric aldol additions: A guided-inquiry laboratory activity on catalysis. Journal of Chemical Education, 95(1), 158-163. doi: 10.1021/acs.jchemed.7b00147.

Lechtanski, V. L. (2001). Inquiry-based experiments for chemistry. Journal of Chemical Education, 78(5), 593. doi: 10.1021@ed078p593.2.

Limoto, D. S., \& Frederick, K. A. (2011). Incorporating student-designed research projects in the chemistry curriculum. Journal of Chemical Education, 88, 1069-1073. doi: $10.1021 /$ ed1011103.

Mbajiorgu, N., \& Reid, N. (2006). Factors influencing curriculum development in chemistry. Hull, UK: Royal Society of Chemistry.

McCroskey, J. C., \& McCroskey, L. L. (1988). Self-report as an approach to measuring communication competence. Communication Research Report, 5(2), 107-113. 
McDonnell, C., O’Connor, C., \& Seery, M. K. (2007). Developing practical chemistry skills by means of student-driven problem-based learning mini projects. Chemistry Education Research and Practice, 8(2), 130-139. doi: 10.1039/B6RP90026G.

Mertens, D. M. (2015). Research and evaluation in education and psychology: Integrating diversity with quantitative, qualitative, and mixed methods. Thousand Oaks, CA: Sage Publications, Inc.

Miller, D. K., \& Lang, P. L. (2016). Using the universal design for learning approach in science laboratories to minimize student stress. Journal of Chemical Education, 93(11), 1823-1828. doi: 10.1021/acs.jchemed.6b00108.

Monteyne, K., \& Cracolice, M. S. (2004). What's wrong with cookbooks? A reply to Ault. Journal of Chemical Education, 81(11), 1559-1560. doi: 10.1021/ed081p1559.

Pickering, M. (1987). What goes on in students' heads in laboratory? Journal of Chemical Education, 64, 521-523. doi: 10.1021/ed064p521.

Pitafi, A. I., \& Farooq, M. (2012). Measurement of scientific attitude of secondary school students in Pakistan. Academic Research International, 2(2), 379-392.

Quitadamo, I. J., \& Kurtz, M. J. (2007). Learning to improve using writing to increase critical thinking performance in general education biology. CBE-Life Sciences Education, 6, 140-154. doi: 10.1187/cbe.06-11-0203.

Reid, N., \& Shah, I. (2007). The role of laboratory work in university chemistry. Chemistry Education Research and Practice, 8(2), 172-185. doi: 10.1039/B5RP90026C.

Rens, L. V., \& Schee, J. V. D. (2009). Teaching molecular diffusion using an inquiry approach. Diffusion activities in a secondary school inquiry-learning community. Journal of Chemical Education, 86(12), 1437. doi: 10.1021/ed086p1437.

Reynolds, J. A., Thaiss, C., Katkin, W. \& Thompson, J. (2012). Writing-to-learn in undergraduate science education: A community-based, conceptually driven approach. CBE Life Sciences Education, 11, 17-25.

Rollnick, M., Zwane, S., Staskun, M., Lotz, S., \& Green, G. (2001). Improving prelaboratory preparation of first year university chemistry students. International Journal Science Education, 23(10), 1053-1071. doi: 10.1080/09500690110038576.

Rootman-le Grange, I., \& Retief, L. (2018). Action research: Integrating chemistry and scientific communication to foster cumulative knowledge building and scientific communication skills. Journal of Chemical Education, 95(8), 1284-1290. doi: 10.1021/acs.jchemed.7b00958.

Saavedra, A. R., \& Opfer, V. D. (2012). Teaching and learning $21^{\text {st }}$ century skills: Lessons from the Learning Sciences. London: RAND Corporation.

Sampson, V., Enderle, P., Grooms, J., \& Witte, S. (2013). Writing to learn by learning to write during the school science laboratory: Helping middle and high school students 
develop argumentative writing skills as they learn core ideas. Science Education, 97(5) 643-670. doi: 10.1002/sce.21069.

Sedwick, V., Leal, A., Turner, D., \& Kanu, A. B. (2018). Guided inquiry learning experience in quantitative analysis. Journal of Chemical Education, 95(3), 451-455. doi: 10.1021/acs.jchemed.7b00336.

Sigler, E. A., \& Saam, J. (2007). Constructivist or expository instructional approaches: Does instruction have an effect on the accuracy of judgment of learning (JOL)? Journal of the Scholarship of Teaching and Learning, 7(2), 22-31. Retrieved from https://josotl.indiana.edu/article/view/1680/1678.

Tsaparlis, G., \& Gorezi, M. (2007). Addition of a project-based component to a conventional expository physical chemistry laboratory. Journal of Chemical Education, 84(4), 668-670. doi: 10.1021/ed084p668.

Velasco, J. B., Knedeisen, A., Xue, D., Vickrey, T. L., \& Abebe, M. (2016). Characterizing instructional practices in the laboratory: The laboratory observation protocol for undergraduate STEM. Journal of Chemical Education, 93(7), 1191-1203. doi: 10.1021/acs.jchemed.6b00062.

Visser, T., Maaswinkel, T., Coenders, F., \& McKenney, S. (2018). Writing prompts help improve expression of conceptual understanding in chemistry. Journal of Chemical Education, 95(8), 1331-1335. doi: 10.1021/acs.jchemed.7b00798.

Wagner, T. (2008). The global achievement gap: Why even our best schools don't teach the new survival skills our children need - and what we can do about it. New York, NY: Basic Books.

Walker, J. P., \& Sampson, V. (2013). Argument-driven inquiry: Using the laboratory to improve undergraduates' science writing skills through meaningful science writing, peer-review, and revision. Journal of Chemical Education, 90(10) 1269-1274. doi: 10.1021/ed300656p.

Winkelmann, K., Baloga, M., Marcinkowski, T., Giannoulis, C., Anquandah, G., \& Cohen, P. (2015). Improving students' inquiry skills and self-efficacy through researchinspired modules in the general chemistry laboratory. Journal of Chemical Education, 92(2), 247-255. doi: 10.1021/ed500218d.

$\mathrm{Xu}, \mathrm{H} .$, \& Talanquer, V. (2013). Effect of the level of inquiry on student interactions in chemistry laboratories. Journal of Chemical Education, 90(1), 29-36. doi: 10.1021/ed3002946. 